Magnus Oscarsson has a teacher education in physics and mathematics for upper secondary school. He is teacher educator at Mid Sweden University in Härnösand and graduate student at the Swedish national graduate school in science and technology education research (FontD). He has carried out the ROSE study in Sweden and is assistant national project manager for OECD/PISA in Sweden.

Anders Jidesjö has a teacher education in science and technology for secondary school and a master degree in science. He is working at the University of Linköping in Sweden at the research department of water and environmental studies. He is one of the graduate students in the Swedish national graduate school in science and technology education research (FontD) and has carried out the ROSE study in Sweden.

Helge Strömdahl är professor i naturvetenskapernas didaktik vid Linköpings Universitet och förestådare för den Svenska Nationella Forskarskolan i Naturvetenskapernas och Teknikens Didaktik (FontD).

KG Karlsson is senior lecture at Mid Sweden University and National Project Manager for OECD/PISA in Sweden

\title{
MAGNUS OSCARSSON
}

Mid Sweden University

magnus.oscarsson@miun.se

ANDERS JIDESJÖ

Linköping University

anders.jidesjo@liu.se

HELGE STRÖMDAHL

Linköping University

helge.stromdahl@isv.liu.se

KARL-GÖRAN KARLSSON

Mid Sweden University

kg.karlsson@miun.se

\section{Science in society or science in school: Swedish secondary school science teachers' beliefs about science and science lessons in comparison with what their students want to learn}

\section{Abstract}

This article presents comparisons concerned with secondary school science teachers' and their students' beliefs about science and technology and also what science content secondary science teachers teach and what their students want to learn. Student data are part of the Relevance of Science Education (ROSE) study and the teacher data are part of an extensive study carried out only in Sweden. The results indicate that both secondary science teachers and their students are optimistic about science and technology as essential parts of societal development. When content from these knowledge fields is considered for instruction, significant disparities exist between what teachers teach and what their students want to learn. Additional results concerning the secondary science teachers' beliefs, 'out-ofschool experiences', 'Science Technology and Society' (STS) approaches and 'inquiry-based instruction' are pointed out as important for the development of science instruction in secondary schools. The results are discussed in the contexts of students' voices and teachers' beliefs. 


\section{INTRODUCTION}

There is a new volume of research concerned with students' attitudes towards science. One problem area is the recruitment of future professionals and consequently, there is a main concern in many countries about the declining trend in the number of students pursuing science education (George, 2006). Another problem is concerned with the establishment of a scientific literacy approach in compulsory schools, not solely concentrating on recruitment but on educating everyone for a citizenship in which science and technology constitute an essential part (Bybee, 1997; DeBoer, 2000; Fensham, 2000; Kolstoe, 2000; Osborne \& Collins, 2001). These two purposes of science at compulsory level are treated by Millar (2006) as 'pre-professional training for some' or 'scientific literacy for all' and can be recognized also in 'vision 1' and 'vision 2' for science education as expounded by Roberts (2007a;b). Pointed out by den Brok, Fischer and Scott (2005), little research has been done into what makes the teaching of science effective in the eyes of the students, a perspective critically reviewed by Jenkins (2006). Lyons (2006) compared students' experiences of school science in different countries and found similarities in compliance with three themes, i.e. 'decontextualized content', 'transmissive pedagogy' and 'unnecessary difficulties'. Listening to the learners delivers the message that secondary science content in school does not connect to the real world, it is uncommunicative and thereby bound by authority instead of showing how evidence is produced by practical work and inferences that involve discussions in a sense of community.

Osborne and Collins (2001) provide data from a focus-group study with students and in all their groups, students emphasise the importance of teachers, specifically in the way they present the science content and organise the work. In a review of students' attitudes towards science (Osborne, Simon \& Collins, 2003) there is substantial evidence pointing to the significance of teachers and teacher styles. They also point out that students seem to be more in line with science in society, which means that contemporary socio-scientific issues are important for the students' perceived relevance. School science seems to offer mostly a backward-looking view of well-established scientific knowledge while students' interests are concerned with what is of immediate importance and the future. Hence, if school science is estranged from 'science in society' it can be expected to have negative consequences for the learners' perceived relevance. Lyons (2006) as well as Osborne et al. (2003) point out that many students like science the way it is presented by other actors in society but dissociate from the way it is treated in school. Likewise, Braund and Reiss (2006) point out the need for the contribution of out-of-school experiences to make science in school more authentic. From this, one question to ask is what opinions secondary science teachers' and their students' have about science and technology in society and in school. Another question is what secondary science teachers teach in comparison to what their students want to learn.

One way to understand teachers' teaching is to carry out research into teachers' beliefs (Pajares, 1992). They can be good indicators of decisions and actions but are defined in many ways by different people and are hard to measure. Beliefs can develop into attitudes and values and they are best understood by looking at what a person 'says, intends and does' which implies putting beliefs into a broader 'belief system'. Tsai (2002) found that science teachers' beliefs about teaching science, learning science and their apprehension of the nature of science (NOS), are often related in a belief system, called 'nested epistemologies', which influences how instruction is carried out. Almost all teachers in his study held a traditional view in all three dimensions. In short this means that teaching science is regarded as transferring knowledge to the students and learning science as reproducing a set of well-established truths. This implies that if any of these aspects are to be changed there need to be changes in all three dimensions. What the relationship to science content is needs further research. Tsai (2007) further develops this by showing how teachers' 'scientific epistemological views' vary across various dimensions and are related to how instruction is formed. There was no strong relationship to the students' 'scientific epistemological views', but a strong relationship to how they perceive science learning environments. Newton and Newton (2001) point to the fact that teachers with less content knowledge rarely interact with their stu- 
dents in subject-relevant and causal questions. den Brok et al. (2005) explain the importance of interaction as understood by 'influence' and 'proximity', for students' attitudes (see also Jarvis \& Pell, 2004). Waters-Adams (2006) adds to this by emphasizing that there is no linear relation between knowledge and putting it into practice. This complexity was not described until as late as the 1990s. Beliefs about 'teaching science', 'teaching children' and 'understanding of NOS', develop with teaching experience. All three aspects need to be considered because they influence each other. Keys (2005) shows that the intended curriculum is never fully implemented and describes four expressed beliefs, 'platonic', 'organizational', 'associated' and 'transitional'. When these beliefs are not implemented, teachers explain this as being caused by lack of provision of resources, time and professional support. Keys calls for more research into teachers' beliefs, which can provide information about how to bridge the gap between the intended and enacted curriculum. The same type of question was raised in 1979 by Galton and Eggleston (1979).

Is there any way to take this further? It seems to be hard to establish an agenda in school science that is more attuned to the needs of children (Brown \& Melear, 2005). They propose inquirybased projects as one way to develop further and seek relationships between teachers' beliefs and actions. In their study, teachers say that they like inquiry-based instruction but often their actions are not in line with this approach. Trumbull, Scarano and Bonney (2006) confirm this and point to underlying beliefs about teaching and learning as the most important factors that need to be reflected on. Bencze, Bowen and Alsop (2006) also point in this direction. Teachers 'scientific theory profiles' can be understood from two continuums, realist to anti-realist and rationalist to naturalist. Those with an orientation towards naturalist/anti-realist profiles were more inclined to put forward student-directed and open-ended projects, drawn from history, philosophy and the sociology of science. Watts, Alsop, Gould and Walsh (1997) show how students' questions cause critical incidents that teachers have to reflect upon. Those reflections involve becoming learner sensitive, thinking about NOS and the aims of science education. Another way to become learner sensitive is to ask the students to write down questions they would like to ask instead of asking what they think is difficult (Mashill \& Pedrosa de Jesus, 1997). The students have relevant questions, they can formulate them and they do not fall into alternative conceptions but rather reflect on their lack of understanding. van Zee, Iwasyk, Kurose, Simpson and Wild (2001), further elaborate this. They identified four aspects that help to establish interaction between students and teachers. Firstly, that students ask questions when they are invited to do so, secondly, that students ask about contexts they have experienced, thirdly, that students feel safe and secure in a learning environment so that different ways of looking at things can be examined and fourthly, work in small groups where students can talk without the teacher interfering. The teachers' role is to direct the students towards conceptual understanding and ask them to elucidate and explain. Martín-Díaz (2006) adds that teachers' educational background and teaching experiences are also important for being able to bring in new content and this should be considered in in-service training (see also Jarvis \& Pell, 2004). Sabatini and McLoughlin (1999) describe the importance of how to educate prospective teachers to make science relevant, both for them and subsequently for the students.

Tan (1988) demonstrates how a curriculum is part of the development of a culture. Science is embedded in the educational system from the increasing needs of public welfare and the population. Due to social concerns and the need for relevance, reforms in teaching science should be based on the recognized needs, economic realities and characteristics of the socio-cultural environment. Bennett, Lubben and Hogarth (2007) reviewed the effects of context-based and STS approaches in eight different countries and found evidence that these approaches improve both girls' and boys' attitudes towards school science, reduce gender differences in attitudes and do not worsen their achievements (see also Mee-Kyeong \& Erdogan, 2007).

It seems that the students' alienation from secondary school science has a lot to do with teacher variables and out-of-school approaches. The aim with this paper is to investigate these questions. 
Results are presented from a comparative study of secondary science teachers and their students. The first part constitutes a comparison between secondary science and technology teachers' and their students' opinions about science and technology. The second part deals with what content science and technology teachers teach in secondary schools in comparison with what their students want to learn. The third part is not comparative, instead it presents data about secondary science and technology teachers' beliefs about their science lessons together with details about what they believe is important for their students' interests. It also considers what sources of inspiration have an influence on the teachers' planning of science lessons and selection of contents. The student data are part of a large worldwide research project, the 'Relevance of science Education' (ROSE) study, under the direction of Professor Svein Sjøberg, University of Oslo. The teacher data have been generated by an extensive study inspired and enlarged from ROSE and has been carried out only in Sweden. The national findings are analyzed on the basis of the following research questions:

- What are the differences between the opinions of secondary science teachers and their students with regard to science and technology?

- What are the differences between what secondary science teachers teach and what their students want to learn?

- What are secondary science teachers' beliefs concerning what is important for their students' interests and what guides their selection of science content in school?

\section{Methodology}

In ROSE a questionnaire divided into eight different categories is used with items on a four-graded Likert-scale. In this paper data from two categories are presented. All other parts of the ROSE study including background, development, limitations, rationale, underlying ideas, data collection and methodological issues are critically described in Schreiner and Sjøberg (2004).

The first category presented in this paper is 'My opinions about science and technology' which consists of sixteen statements about the relevance of science and technology in society including some statements about scientists and their work. The endpoints of the scale in this category are 'disagree' and 'agree'. The teachers and their students have all answered the same questions.

The second part uses data from the student questionnaire in the category 'What I want to learn about' with subheading 'How interested are you in learning about the following?' consisting of 108 items. This category contains questions concerning astrophysics, earth science, human biology with sex and reproduction, genetics, zoology, botany, chemistry, optics, acoustics, electricity, energy, technology, 'Science, Technology and Society' (STS) and 'Nature of Science' (NOS). The questions are put in different contexts such as: spectacular phenomena, fear, technological ideas and inventions, aesthetical aspects, beauty, care, health, personal use and everyday relevance. The teacher questionnaire was developed from the student questionnaire. The question 'What I want to learn about' was changed to 'What I teach about' with the subheading 'To what extent do you bring up the following in your instruction'. The endpoints of the scale were changed from 'not interested - very interested' to 'not at all - thoroughly'. Otherwise every item throughout this category was kept and asked to the students' teachers. These two data sets make a comparison possible between what secondary science teachers teach and what their students want to learn.

The third and last part present 'teachers' opinions about their science lessons' with three data sets. The first is concerned with 'This is important for the students' interest in science' with 21 questions, the second with 'This is guiding me when I plan my lessons' with 19 questions and the third with 'To what extent do you agree with the following statements about science instruction' with 20 questions. 
In the creation of the Swedish student questionnaire, the English original version was translated and then the Norwegian questionnaire was used to make comparisons and check for possible indistinctness. The translation was made as verbatim as possible without losing shades of meaning. Furthermore, other researchers read the translation and compared it with the English original. From this, a revised and final version was constructed.

In the teacher questionnaire only the way of phrasing the questions were changed. In the categories presented in this paper all items were kept the same and can therefore be found in Schreiner and Sjøberg (2004). The additional questions, asked only to the teachers, are all presented in the third part of this paper. A final version of the teacher questionnaire was tested on some science teachers to eliminate indistinct items or wordings that were difficult to understand. From this, the final version was created.

\section{THE SAMPLE}

In 2003 the student cohort aged 15 in Sweden (ninth and last year in the Swedish compulsory school system) comprised about 110000 individuals distributed over 1577 schools. This information was supplied from the national Swedish statistics agency 'Statistics Sweden' (http://www.scb. se). From these, 30 schools were randomly selected out of a sample with nine stratum variables to assure correct weight for each type of school. Those variables are the same as in the OECD/ PISA study to ensure a national sample. The schools themselves selected one class each. The size of the classes varied from 20 to 35 students with the exception of one class with 15 students. A test-assistant visited each school, gave information about the project, distributed the questionnaires and later collected them. Nothing problematical was reported regarding data collection from a total of 751 students in 29 schools. Further details about the student sample are described in a technical report (Oscarsson \& Jidesjö, 2005). The teacher questionnaire was sent by mail to all the 29 schools where student data were collected. In each school there was a contact person who carried them out with colleagues and sent them back by mail. Teacher data were collected in late spring 2004 with a total sample of 110 .

\section{SWEDISH SCHOOL SCIENCE IN COMPULSORY LEVEL: SCIENCE STUDIES}

The current science curriculum is from the year 2000 and the directive is described in terms of 'goals to aim for in science studies'. There are goals that students should have attained by the end of the fifth and the ninth year. Three aspects recur throughout the science curriculum, i.e. 'knowledge of nature and Man', 'scientific activity' and 'use of knowledge'. There are descriptions of physics, chemistry and biology and a common science curriculum. The different parts support and complement each other to fulfil the national task. Furthermore, the field of science studies is linked to knowledge in other subjects in the school curriculum. The wording depicts science as a process developed through human activity, as the joy of discovery, as important for democracy, as a central part of Western cultural tradition and stresses the need for sustainable development. When it comes to the selection of content, and the use of different teaching methods and materials, teachers are free to choose as long as their students reach the capabilities postulated in the goals to aim for (the National Swedish Agency for Education, 2006).

\section{RESULTS}

Secondary science teachers' and their students'opinions about science and technology

Table 1 presents 16 statements about science and technology ranked according to the mean values of secondary science teachers. In addition, students' means for girls' and boys' respectively for the same items are presented. 
Table 1. Secondary science teachers' opinions about science and technology compared with their students' opinions on the same statements, girls' and boys' respectively. The list is ranked according to teacher means in falling order, with standard deviations (S.D.) and means for boys and girls.

1=disagree $4=$ agree

\begin{tabular}{|c|c|c|c|c|}
\hline & Statement & $\begin{array}{l}\text { Teacher } \\
\text { mean (S.D.) }\end{array}$ & $\begin{array}{l}\text { Girls } \\
\text { mean }\end{array}$ & $\begin{array}{l}\text { Boys } \\
\text { mean }\end{array}$ \\
\hline 1. & Science and technology are important for society & $3.90(0.31)$ & 3.08 & 3.07 \\
\hline 2. & $\begin{array}{l}\text { A country needs science and technology to become } \\
\text { developed }\end{array}$ & $3.68(0.47)$ & 3.03 & 2.99 \\
\hline 3. & $\begin{array}{l}\text { Science and technology will find cures to diseases } \\
\text { such as HIVIAIDS, cancer, etc. }\end{array}$ & $3.60(0.63)$ & 3.25 & 3.02 \\
\hline 4. & $\begin{array}{l}\text { Thanks to science and technology, there will be } \\
\text { greater opportunities for future generations }\end{array}$ & $3.55(0.66)$ & 3.03 & 2.99 \\
\hline 5 . & Scientific theories develop and change all the time & $3.47(0.65)$ & 2.99 & 2.82 \\
\hline 6. & $\begin{array}{l}\text { The benefits of science are greater than the harmful } \\
\text { effects it could have }\end{array}$ & $3.43(0.72)$ & 2.74 & 2.88 \\
\hline 7. & $\begin{array}{l}\text { Science and technology benefit mainly the devel- } \\
\text { oped countries }\end{array}$ & $3.27(0.77)$ & 2.84 & 2.90 \\
\hline 8. & $\begin{array}{l}\text { Science and technology make our lives healthier, } \\
\text { easier and more comfortable }\end{array}$ & $3.02(0.77)$ & 2.50 & 2.66 \\
\hline 9. & New technologies will make work more interesting & $2.92(0.85)$ & 2.54 & 2.87 \\
\hline 10. & $\begin{array}{l}\text { Science and technology are the cause of the environ- } \\
\text { mental problems }\end{array}$ & $2.78(0.85)$ & 2.44 & 2.44 \\
\hline 11. & $\begin{array}{l}\text { Science and technology will help to eradicate pov- } \\
\text { erty and famine in the world }\end{array}$ & $2.43(0.91)$ & 2.12 & 2.20 \\
\hline 12. & Science and technology are helping the poor & $2.38(0.80)$ & 1.85 & 2.10 \\
\hline 13. & Science and technology can solve nearly all problems & $2.00(0.83)$ & 1.80 & 2.13 \\
\hline 14. & $\begin{array}{l}\text { Scientists follow the scientific method that always } \\
\text { leads them to correct answers }\end{array}$ & $1.84(0.81)$ & 2.05 & 2.31 \\
\hline 15. & Scientists are neutral and objective & $1.63(0.70)$ & 1.80 & 2.02 \\
\hline 16. & We should always trust what scientists have to say & $1.50(0.62)$ & 1.49 & 1.74 \\
\hline
\end{tabular}

Secondary science teachers seem to be positive to science and technology in general, optimistic that it can help solve diseases and believe that these knowledge fields develop and change continually. They also show scepticism that scientists should always be trusted and are always neutral and objective and that science and technology can solve all problems. There is more ambivalence to if science and technology can help the poor and if they can assist in eradicating poverty and famine in the world. When comparing the teachers' rankings with their students' an almost identical pattern is displayed with slightly lower means among the students. Both boys and girls rank those statements in almost the same falling order as their teachers. The next step in this analysis is to investigate what science content that should be considered for instruction in school. 


\section{What secondary science teachers teach and what their students want to learn about}

This analysis is done first in Table 2 where the first 20 items out of 108 are ranked according to teachers' selection of content compared with what their students want to learn. Teacher means are presented and compared with their students' ranking, i.e. the position of the same items when they are ranked according to students' means, by girls and boys respectively.

Table 2. Teachers' selection of content compared with what their students want to learn. The list is ranked according to teachers' means in falling order and presents the first 20 items with highest means and standard deviations (S.D.) out of 108. The comparison with students is presented with the position those items get by the students' when ranked according to means for girls and boys respectively.

$1=$ never, $4=$ thoroughly

\begin{tabular}{|c|c|c|c|c|}
\hline & Topic & $\begin{array}{l}\text { Teacher mean } \\
\text { (S.D.) }\end{array}$ & $\begin{array}{l}\text { Girls } \\
\text { ranking }\end{array}$ & $\begin{array}{l}\text { Boys } \\
\text { ranking }\end{array}$ \\
\hline 1. & Atoms and molecules & $3.56(0.66)$ & 98 & 73 \\
\hline 2. & $\begin{array}{l}\text { The greenhouse effect and how it may be changed } \\
\text { by humans }\end{array}$ & $3.31(0.77)$ & 60 & 68 \\
\hline 3. & How the human body is built and functions & $3.31(1.09)$ & 22 & 51 \\
\hline 4. & $\begin{array}{l}\text { Electricity, how it is produced and used in the } \\
\text { home }\end{array}$ & $3.25(0.90)$ & 102 & 50 \\
\hline 5. & How alcohol and tobacco might affect the body & $3.21(1.01)$ & 6 & 23 \\
\hline 6. & How the ear can hear different sounds & $3.20(0.92)$ & 71 & 74 \\
\hline 7. & $\begin{array}{l}\text { How people, animals, plants and the environment } \\
\text { depend on each other }\end{array}$ & $3.16(0.86)$ & 70 & 80 \\
\hline 8. & $\begin{array}{l}\text { The ozone layer and how it may be affected by } \\
\text { humans }\end{array}$ & $3.14(0.80)$ & 57 & 70 \\
\hline 9. & Sex and reproduction & $3.13(1.19)$ & 23 & 30 \\
\hline 10. & How the eye can see light and colours & $3.07(0.87)$ & 58 & 71 \\
\hline 11. & $\begin{array}{l}\text { Heredity, and how genes influence how we de- } \\
\text { velop }\end{array}$ & $3.03(1.18)$ & 21 & 62 \\
\hline 12. & $\begin{array}{l}\text { How loud sound and noise may damage my hear- } \\
\text { ing }\end{array}$ & $3.03(0.93)$ & 42 & 44 \\
\hline 13. & $\begin{array}{l}\text { New sources of energy from the sun, wind, tides, } \\
\text { waves, etc. }\end{array}$ & $3.03(0.83)$ & 65 & 21 \\
\hline 14. & Chemicals, their properties and how they react & $2.99(1.05)$ & 87 & 66 \\
\hline 15. & $\begin{array}{l}\text { Sexually transmitted diseases and how to be pro- } \\
\text { tected against them }\end{array}$ & $2.98(1.19)$ & 9 & 43 \\
\hline 16. & How different narcotics might affect the body & $2.96(1.04)$ & 4 & 25 \\
\hline 17. & Birth control and contraception & $2.93(1.21)$ & 17 & 65 \\
\hline 18. & How my body grows and matures & $2.92(1.10)$ & 14 & 38 \\
\hline 19. & $\begin{array}{l}\text { Inventions and discoveries that have changed the } \\
\text { world }\end{array}$ & $2.88(0.76)$ & 51 & 26 \\
\hline 20. & What to eat to keep healthy and fit & $2.86(0.96)$ & 5 & 32 \\
\hline
\end{tabular}


Many of the items teachers lay stress on are ranked lowly by their students. Secondary science instruction seems to be in line with the students views only when it comes to 'alcohol and tobacco' and 'sexually transmitted diseases'. Some of the items teachers teach a lot, are at the lower end of the girls' ranking with the boys closely above. If the secondary students do not want to learn about many of the items that their science teachers teach, what then do they want to learn about and what is the teachers' ranking of those items according to their means? This is presented in Table 3 with the 20 first items out of 108 .

Table 3. What secondary students want to learn about in science and technology compared whit their teachers' selection of science content. The list is ranked according to students' means in falling order and presents the 20 first items with highest means and standard deviations (S.D.) out of 108. The comparison with teachers is presented with the position those items get by the teachers when ranked according to their means.

$1=$ Not interested, $4=$ Very Interested

Statement

1. How to exercise to keep the body fit and strong

2. How it feels to be weightless in space

3. The possibility of life outside earth

4. Why we dream while we are sleeping, and what the

4. dreams may mean

5. How different narcotics might affect the body

6. How alcohol and tobacco might affect the body

7. What to eat to keep healthy and fit

8. What we know about HIVIAIDS and how to control it

9. How to perform first-aid and use basic medical equipment

10. Phenomena that scientists still cannot explain

11. Thought transference, mind-reading, sixth sense, intuition, etc

Sexually transmitted diseases and how to be protected against them

13. Cancer, what we know and how we can treat it

14. How meteors, comets or asteroids may cause disasters on earth

15. How my body grows and matures

16. How computers work

17. Sex and reproduction

18. Black holes, supernovas and other spectacular objects in outer space

19. How to protect endangered species of animals

20. Unsolved mysteries in outer space
Student Mean

(S.D.)

$3.03(0.96)$

$3.00(1.02)$

$2.93(1.05)$

$2.93(1.06)$

$2.84(1.00)$

2.83 (0.98)

2.81 (1.02)

$2.80(1.01)$

2.79 (1.00)

$2.77(1.12)$

2.77 (1.11)

2.76 (0.97)

$2.74(1.03)$

2.71 (1.04)

2.69 (1.00)

2.69 (1.03)

2.68 (0.94)

$2.67(1.11)$

$2.65(1.02)$

$2.65(1.12)$
Teacher ranking

65

73

38

101

16

5

20

30

61

53

106

15

52

57

18

75

9

44

66

93 
Many of the things that students put forward as interesting to learn about are ranked lowly by their teachers. In Table 2 and 3 the disparities are almost like two different agendas and it is when it comes to science content in secondary schools, as seen from the teachers' and the learners' perspectives, that these two separate agendas appear. The next step in this analysis is to look more in detail at secondary science teachers' opinions about their science lessons.

\section{Secondary science teachers'opinions about their science lessons}

To understand something about the disparities in content orientations presented in Table 2 and 3 , the continuation of this analysis turns to more detailed data concerning teachers' beliefs about their science lessons. The first data set is concerned with what the teachers believe is important for students' interests in science and technology, presented in Table 4.

Table 4. Teachers' opinions about their science lessons - 'This is important for students' interests in science'. Means, standard deviations (S.D.) and standard errors (S.E.).

$1=$ disagree $4=$ agree

\begin{tabular}{|c|c|c|c|c|}
\hline & Statement & Mean & S.D. & S.E. \\
\hline 1. & Laboratory work & 3.8 & 0.4 & 0.04 \\
\hline 2. & When instruction is about important questions in society & 3.5 & 0.5 & 0.05 \\
\hline 3. & $\begin{array}{l}\text { When students are allowed to tell what they know or what } \\
\text { they have experienced }\end{array}$ & 3.5 & 0.6 & 0.06 \\
\hline 4. & Be in nature & 3.5 & 0.6 & 0.06 \\
\hline 5. & Do field trips & 3.5 & 0.6 & 0.06 \\
\hline 6. & Play with science kits or technological tools & 3.4 & 0.6 & 0.06 \\
\hline 7. & Instruction by the teacher & 3.4 & 0.6 & 0.06 \\
\hline 8. & Do study tours & 3.3 & 0.6 & 0.05 \\
\hline 9. & When the class have dialogues with the teacher & 3.1 & 0.7 & 0.07 \\
\hline 10. & Talk in private with the teacher & 3.0 & 0.7 & 0.07 \\
\hline 11. & Watch TV & 3.0 & 0.6 & 0.06 \\
\hline 12. & Read in other books & 3.0 & 0.7 & 0.07 \\
\hline 13. & Get into contact with companies working with science & 2.9 & 0.8 & 0.08 \\
\hline 14. & Read in science school books & 2.9 & 0.7 & 0.07 \\
\hline 15. & Write compositions & 2.9 & 0.8 & 0.08 \\
\hline 16. & Take notes from the blackboard during expositions & 2.8 & 0.8 & 0.08 \\
\hline 17. & Talk with friends & 2.8 & 0.7 & 0.07 \\
\hline 18. & Write lab reports & 2.7 & 0.8 & 0.08 \\
\hline 19. & Talk with parents & 2.7 & 0.8 & 0.08 \\
\hline 20. & Talk with other adults, friends and relatives & 2.7 & 0.8 & 0.08 \\
\hline 21. & Go to the cinema & 1.9 & 0.8 & 0.08 \\
\hline
\end{tabular}


According to the teachers, almost all statements are important for maintaining students' interests in their science lessons. Out-of-school experiences are ranked highly by the teachers as well as STS-approaches like 'important questions in society'. In addition, experimental work and student centred views are put forward. If 'out-of-school experiences', 'STS-approaches' and to some extent, 'inquiry-based instruction' are believed to be important for the students' interests, in what ways do these influence the selection of contents? This is presented in Table 5 with data on secondary teachers' opinions of what is important for their selection of contents when planning their science lessons.

Table 5. Teachers' opinions about their science lessons - "This is guiding med when I plan my lessons". Means, standard deviations (S.D.) and standard errors (S.E.).

$1=$ disagree, $4=$ agree

\begin{tabular}{|c|c|c|c|c|}
\hline & Statement & Mean & S.D. & S.E. \\
\hline 1. & Curriculum and syllabuses & 3.5 & 0.6 & 0.06 \\
\hline 2. & My own thoughts and ideas & 3.4 & 0.6 & 0.06 \\
\hline 3. & Tip-offs from colleagues & 3.0 & 0.7 & 0.07 \\
\hline 4. & Wishes from students & 3.0 & 0.7 & 0.07 \\
\hline 5. & Local syllabuses & 2.9 & 0.9 & 0.09 \\
\hline 6. & Important questions in society & 2.8 & 0.7 & 0.07 \\
\hline 7. & The textbook and its putting up & 2.6 & 0.8 & 0.08 \\
\hline 8. & Joint planning in working party & 2.5 & 0.9 & 0.09 \\
\hline 9. & Ideas from Internet & 2.4 & 0.7 & 0.07 \\
\hline 10. & Ideas from TV & 2.4 & 0.7 & 0.07 \\
\hline 11. & Popular science magazines & 2.4 & 0.8 & 0.08 \\
\hline 12. & Ideas from daily papers & 2.3 & 0.8 & 0.08 \\
\hline 13. & Wishes or demands from head teacher & 2.2 & 1.0 & 0.10 \\
\hline 14. & Specialist literature from my period of training & 2.1 & 0.8 & 0.08 \\
\hline 15 . & Ideas from radio & 1.8 & 0.8 & 0.08 \\
\hline 16. & Wishes from parents & 1.8 & 0.8 & 0.08 \\
\hline 17. & Contacts with companies & 1.8 & 0.8 & 0.07 \\
\hline 18. & Close friends and people among my acquaintances & 1.7 & 0.7 & 0.07 \\
\hline 19. & Ideas from weekly publication magazines & 1.7 & 0.7 & 0.07 \\
\hline
\end{tabular}

The directive comes out as most highly ranked followed by the teachers' own thoughts and ideas. Many of the items with means below 2.5 are practices outside school. For example, contacts with companies, ideas from Internet and TV seem to have a low impact on the teachers' selection of science content, but are ranked highly by them as important for students' interests in science (Table 4). Can some of these circumstances have an influence on the mismatch in Tables 2 and 3 ? We asked the teachers to tell us about this, presented in Table 6. 
Table 6. Teachers' opinions about their science lessons - 'To what extent do you agree with the following statements about science instruction?' Means, standard deviations (S.D.) and standard errors (S.E.)

$1=$ disagree, $4=$ agree

\begin{tabular}{|c|c|c|c|c|}
\hline & Statement & Mean & S.D. & S.E. \\
\hline 1. & It is possible to make science in school more interesting & 3.6 & 0.6 & 0.06 \\
\hline 2. & Science teaching gives the students an all-round education & $3 \cdot 5$ & 0.6 & 0.05 \\
\hline 3. & The science teaching prepares for everyday life & 3.1 & 0.7 & 0.06 \\
\hline 4. & The students are working a lot with tasks and projects & 2.9 & 0.7 & 0.07 \\
\hline 5. & Science instruction feels up to date and of today & 2.8 & 0.7 & 0.07 \\
\hline 6. & The students are doing a lot of group-work & 2.8 & 0.8 & 0.08 \\
\hline 7. & $\begin{array}{l}\text { Science instruction is clearly connected with the students } \\
\text { everyday life }\end{array}$ & 2.7 & 0.7 & 0.07 \\
\hline 8. & The students are working a lot o their own & 2.7 & 0.7 & 0.07 \\
\hline 9. & Science instruction prepare the students for future work & 2.6 & 0.8 & 0.08 \\
\hline 10. & The students talks a lot and I answer questions & 2.6 & 0.6 & 0.06 \\
\hline 11. & I often need to read over the content I teach about & 2.5 & 1.0 & 0.09 \\
\hline 12. & In science we often work together on our school & 2.4 & 0.9 & 0.09 \\
\hline 13. & In science we often work interdisciplinary & 2.2 & 0.9 & 0.09 \\
\hline 14. & The new syllabus in year 2000 changed what I bring up & 2.2 & 0.9 & 0.10 \\
\hline 15. & The new syllabus in year 2000 changed the instruction & 2.2 & 0.9 & 0.09 \\
\hline 16. & I talk a lot and the students answer questions & 2.1 & 0.7 & 0.07 \\
\hline 17. & The different subjects in science are best taught separately & 2.1 & 1.0 & 0.10 \\
\hline 18. & The students are using the computers a lot & 2.0 & 0.7 & 0.07 \\
\hline 19. & Boys are more interested in science than girls & 1.9 & 0.9 & 0.09 \\
\hline 20. & I am satisfied with the in-service training I get in science & 1.6 & 0.9 & 0.09 \\
\hline
\end{tabular}

Teachers believe that it is possible to make science more interesting and that their students get an all-round education and are being prepared for everyday life, but there is some uncertainty about if science is clearly connected with the students' everyday life. Furthermore, when the new curriculum in science was introduced in Sweden in 2000, neither what is taught nor the instruction changed much according to the teachers. They do not work much together or in an interdisciplinary manner and they are unsatisfied with their in-service training. 


\section{Discussion}

\section{What are the differences between the opinions of secondary science teachers and their students with regard to science and technology?}

From the data presented in this paper there is agreement between science teachers and their students that science and technology are essential parts of contemporary society and the future.

The result show few disparities. Earlier research points to contemporary socio-scientific issues, technology and future challenges as important aspects for young peoples' willingness to participate in science instruction (Osborne et al., 2003). Science teachers agree that science and technology are important for society and that a country needs them to develop. There is also faith that these knowledge fields can solve serious diseases like HIV/AIDS, cancer and that science and technology will make a contribution towards greater opportunities for future generations. For the most part both students and their teachers agree that science and technology make our lives healthier, easier and more comfortable and that new technology will make work more interesting. Another result is that there is ambivalence with regard to if science and technology will help to eradicate poverty and famine in the world and if these knowledge fields are helping the poor. Today, scientists are trying to solve environmental problems and to obstruct poverty traps. The Swedish curriculum also points to questions of globalization and an effort towards a more sustainable exploitation of resources which means that famine and poverty could be important contexts in school science.

Neither the students nor their teachers are negative towards science and technology. Actually, we have found that they hold the same opinions and this is a finding we have found nowhere else in the literature. Nevertheless, when Lyons (2006) analyzed students' experiences of secondary science classrooms he found 'decontextualized content', 'transmissive pedagogy' and 'unnecessary difficulties' as core themes. Sweden is one country in his study. How can this be the case? The learners seem to be critical to school science at the same time as they are, like their teachers, positive to those knowledge fields as contributors to societal development. In what ways those opinions influence secondary science instruction is hard to decide, but ought to be further investigated as there are indications from research presented in the introduction of this paper that science instruction mainly focuses on facts established in the past and does not put much stress on future prospects. As students seem to dissociate themselves from these knowledge fields due to the ways they are dealt with in school, what is it that secondary science teachers cover in their lessons that can produce this kind of hesitance among the students?

\section{What are the differences between what secondary science teachers teach and what their students want to learn?}

Another finding in this paper is the indication that an essential part of the content that is taught in secondary science classrooms is not in alignment with what students want to learn. Science teachers give precedence to contents such as atoms and molecules, the greenhouse effect, electricity, how the ear can hear, how the eye can see, how people, animals, plants and the environment depend on each other, how chemicals react and the ozone layer. These are all items that are far from the students' rankings of the same items. The ones that are somewhat in line are 'how alcohol and tobacco might affect the body', 'sexually transmitted diseases and how to be protected against them' and maybe also 'sex and reproduction'. Our results show that, it is when it comes to specific contents in school, teachers and their students diverge in what they consider relevant. This is a way to make 'teacher variables' more comprehensible. Almost all teachers in Tsai's (2002) study perceived teaching science as transferring knowledge to the students and learning science as the reproduction of a set of well-established truths. When investigating those perspectives further, teachers' 'scientific epistemological views' were found to be strongly connected with how students perceive their science leaning environments (Tsai, 2007). Research that relates teachers' work with specific contents seems to be poorly developed, despite that this topic is important due to the consequences for students' experiences with secondary school science. 
Another approach to the problem is to begin with what students want to learn about and compare those items with the position they were given by the teachers. In doing so, similar divergences are revealed. Students interests are oriented to modern challenges such as health issues, astronomy, diseases and phenomena that scientists cannot explain while school science focuses on for example atoms and molecules, electricity in our homes, how chemicals react, how the eye can see and the ear can hear together with the ozone layer. Another way of expressing it is that young teenagers want to learn about contemporary science while much of the instruction in secondary science classrooms focuses on learning a collection of well-established facts, in line with the discussion of Osborne et al. (2003). What kinds of traditions have an influence on these two agendas? Is this an undesirable situation? And what can we learn from research, paying attention to teachers' and students' views?

\section{What are secondary science teachers' beliefs concerning what is important for their students' interests and what guides their selection of science content in school?}

When asking the teachers about what is important for students to help them take an interest in science, laboratory work comes out as being most important, followed by when teaching is about 'important questions in society'. When 'students are allowed to tell what they know and experience', 'being in nature', 'doing field trips and study tours' and 'playing with science kits' are also mentioned. Surveys, class dialogues and private talks with the teacher are also emphasized. Many of these statements fit the discussion about inquiry-based instruction. Several researchers point to the importance of this approach to take this field further, and secondary science teachers seem to agree. One problem is that this approach appears to be hard to establish (Brown \& Melear, 2005). According to Trumbull et al. (2006) the cause for this is underlying beliefs about teaching and learning. One way to cross this barrier is to listen to the needs of the learners (Watts et al., 1997). Students can formulate relevant questions and express what they would like to learn, for example by writing them down and such information is important when planning lessons (see Mashill \& Pedrosa de Jesus, 1997; van Zee et al., 2001, for a further elaboration). This means that students' perspectives on what is relevant are important in developing school science instruction and several researchers point to a need to reconceptualize science learning practices (see for example Roberts, $2007 a ; b)$. To be student centred requires good content knowledge and being able to maintain discipline and teachers can find it scary to become a co-learner, focusing on the students' progress instead of the subject (Watts et al., 1997). Furthermore, secondary science teachers also rank several out-of-school experiences as being important for students' interest in science and technology: watching e.g. TV, reading other books and contacts with companies working with science. To sum up, secondary science teachers point out both 'inquiry-based instruction' and 'out-of-school experiences' as being important for their students' interests in science education. What then are those teachers being influenced by when selecting contents and planning their science lessons?

Curriculum and syllabuses, own thoughts, colleagues, wishes from students and burning questions in society come out as being most important for the selection of contents and planning of science lessons. It seems as if the instruction is very student centred and society oriented. If this were true, the disparities between what is taught and what students want to learn about would be unexpected. Inconsistencies like these are difficult to interpret. Beliefs about teaching are based on early experiences, hard to change, difficult to measure and central for action (Pajares, 1992). But as several researchers point out, beliefs are not always implemented (Keys, 2005; Tsai, 2002; Waters-Adams, 2006).In today's society it is easy to get information and many different actors treat science and technology content in different ways. This is the starting point for Braund and Reiss (2006) when they emphasize that because the nature of science has changed during the $20^{\text {th }}$ century, the nature of learning science has been challenged and there is a need for increased outof-school experiences to make science in school more authentic. The teachers believe that TV, reading other books and contacts with companies are important for students' interest in science but show ambivalences towards if textbooks, joint planning, Internet, TV, popular science magazines and daily papers are important aspects for the preparation of science lessons. The teachers 
seem to be well aware of these sources of information as being important for students' perceived relevance, but school science lessons are mainly planned from other starting points. Different stakeholders in society, that treat content in different contexts in the way that people want to listen, watch and read their stories, have to a lesser extent influence on science teachers when they plan their lessons. Also, literature from their teacher education programmes is ranked low. Hence, what are the science teacher training programmes busy doing? (also reflected by Lyons, 2006; MartínDíaz, 2006; Sabatini \& McLoughlin, 1999). In a modern society, information is treated by interest groups in different ways due to the different purposes of the groups. From research evidence presented in the introduction of this paper a reasonable suggestion would be that these circumstances are interesting for understanding, from the students' and their teachers' points of views, problems of relevance with science instruction in secondary schools. It is a matter of setting out what societal development implies for social order and information processing and ways that young people encounter school science. Is content selected for students learning processes in the $21^{\text {st }}$ century (Braund \& Reiss, 2006), for scientific literacy in the $21^{\text {st }}$ century (Millar, 2006) or for antiquated views on teaching and learning science (Tsai, 2002)? A thorough comprehension of the purposes behind the selection and treatment of content by science teachers is likely to be one important part in making school science relevant in the eyes of the learners.

Secondary science teachers believe that it is possible to make science instruction more interesting and that it prepares students for everyday life. This is not in line with Lyons (2006) results when the students describe their experiences of science lessons. There seems to be a mismatch between the teachers' apprehensions and students' experiences. The teachers in our study show some uncertainty about if science instruction is up to date and modern. How can science instruction prepare for everyday life if it is not up to date and current? Most of the teachers do not believe that the different science subjects are best taught separately, but they do not work much together, nor do they work in an interdisciplinary manner. According to the teachers, when the new syllabuses in science were introduced in 2000, they did not have any significant effect on neither what they take up nor the instruction. In PISA 2006 Swedish students show distinctly higher competence in knowledge in science compared with knowledge about science (OECD, 2006; 2007). Competencies such as using scientific evidence are also weak areas and these failings indicate that the new science syllabuses from 2000 are poorly implemented. At the same time, the teachers are very dissatisfied with their in-service training.

Pajares (1992) points to the fact that beliefs develop into values and attitudes, and that the best way to understand the relationship between beliefs and practice is to study belief systems. WatersAdams (2006) means that beliefs about teaching science, teaching children and understanding the nature of science develop with teaching experience, in line with Tsais' (2002) nested epistemologies. This complexity has been further developed by showing that teachers' 'scientific epistemological views' vary across different dimensions and are related to how instruction is formed (Tsai, 2007) but the relationship to contents is poorly developed (Tsai, 2002).

In this paper we contribute with concrete dimensions of teachers' beliefs about their science lessons. The distinction between what secondary science teachers teach and what their students want to learn about and their beliefs about science and technology, indicate that connections between teachers' beliefs and content taught in the classroom are complex matters and need to be further investigated. To progress further, some researchers propose inquiry oriented learning environments and students' questions as fundamentals of becoming student oriented and learner sensitive (Watts et al., 1997). The point is not to charge teachers with the responsibility, but instead to try to go into particulars about the problem. It is when it comes to specific contents in secondary schools that 'what teachers teach' and 'what students want to learn' diverge from each other. Maybe it is time to start listening with a keen ear to those affected by secondary school science, i.e. the teachers and their students and tone down other groups, like universities, with an interest in deciding what school science should be about and how it should be treated (see also Lyons, 2006). 


\section{CONCLUSIONS}

There are interesting findings presented in this paper. Firstly, secondary science teachers and their students seem to have the same opinions about science and technology. They are both positive about these knowledge fields as being important contributors to societal development. Secondly, when it comes to what science and technology content are taught in secondary schools, there seems to be a disparity between what teachers teach and what their students want to learn. It is like two different agendas. Thirdly, when trying to understand what guides the teachers when selecting this content it is like opening up a complex landscape of problems. Many out-of-school experiences are believed by the teachers to be important for young people's interests in science, but several of these areas are not essential when they plan their lessons. The teachers know a lot about what they would like to do and what is important for their students' interests, but have they been left alone? It is highly demanding work to put research results into practice. To help teachers improve secondary school science, collaboration is needed and research that relates teachers' belief systems to specific science content are important, but poorly developed.

Tan (1988) demonstrated the importance of understanding curriculum changes in science in relation to cultural development. Science in school is embedded in the educational system from the perspectives of public welfare, recognized needs, economic realities and characteristics of the socio-cultural milieu. This is a concrete example of science in school functioning from social concerns and the need for relevance. Therefore, to understand societal development becomes crucial, and if these human elements are ignored science in schools will appear to be irrelevant rather than helping humanity. In a modern world where due to globalization actions and merchandise are indissolubly intertwined between countries, these perspectives, attuned to the needs of the children, have never been of more vital importance for science education than today.

\section{ACKNOWLEDGEMENTS}

We thank the teachers and their students who completed the questionnaires; colleagues in the Department of Teacher Education and School Development at the University of Oslo for cooperation and advice on a number of matters, and all other ROSE partners around the world.

\section{REFERENCES}

Bencze, J. L., Bowen, G. M., \& Alsop, S. (2006). Teachers' tendencies to promote student-led science projects: Associates with their views about science. Science Education, 90(3), 400-419.

Bennett, J., Lubben, F., \& Hogarth, S. (2007). Bringing science to life: A synthesis of the research evidence on the effects of context-based and STS approaches to science teaching. Science Education, 91(3), 347-370.

Braund, M., \& Reiss, M. (2006). Towards a more authentic science curriculum: The contribution of out-of-school learning. International Journal of Science Education, 28(12), 1373-1388.

Brown, S. L., \& Melear, C. T. (2005). Investigation of secondary science teachers' beliefs and practices after authentic inquiry-based experiences. Journal of Research in Science Teaching, 43(9), 938-962.

Bybee, R. W. (1997). Achieving scientific literacy: From purposes to practices. Portsmouth, NH: Heinemann.

DeBoer, G. (2000). Scientific literacy: Another look at its historical and contemporary meanings and its relationship to science education reform. Journal of Research in Science Teaching, 37(6), 582-601.

den Drok, P., Fisher, D., \& Scott, R. (2005). The importance of teacher interpersonal behaviour for student attitudes in Brunei primary science classes. International Journal of Science Education, 27(7), 765-779. 
Fensham, P. (2000). Providing suitable content in the "science for all" curriculum. In R. Millar, J. Leach \& J. Osborne (Eds.). Improving science Education: The Contribution of research. Buckingham: Open University Press.

Galton, M., \& Eggleston, J. (1979). Some characteristics of effective science teaching. International Journal of Science Education, 1(1), 75-86.

George, R. (2006). A Cross-domain Analysis of Change in Students' Attitudes toward science and attitudes about the utility of science. International Journal of Science Education, 28(6), 571589.

Jarvis, T., \& Pell, A. (2004). Primary teachers' changing attitudes and cognition during a two-year science in-service programme and their effect on pupils. International Journal of Science Education, 26(14), 1787-1811.

Jenkins, E. W. (2006). The student voice and school science education. Studies in Science Education, 42(1), 49-88.

Keys, P. M. (2005). Are teachers walking the walk or just talking the talk in science education? Teachers and Teaching: Theory and Practice, 11(5), 499-516.

Kolstoe, S. D. (2000). Consensus projects: teaching science for citizenship. International Journal of Science Education, 22(6), 645-664.

Lyons, T. (2006). Different countries, same science classes: Students' experiences of school science in their own words. International Journal of Science Education, 28(6), 591-613.

Maskill, R., \& Pedrosa de Jesus, H. (1997). Pupils' questions, alternative frameworks and the design of science teaching. International Journal of Science Education, 19(7), 781-799.

Martín-Díaz, M. J. (2006). Educational background, teaching experience and teachers' views on the inclusion of nature of science in the science curriculum. International Journal of Science Education, 28(10), 1161-1180.

Mee-Kyeong, L., \& Erdogan, I. (2007). The effect of science-technology-society teaching on students' attitudes toward science and certain aspects of creativity. International Journal of Science Education, 29(11), 1315-1327.

Millar, R. (2006). Twenty First Century science: Insights from the design and implementation of a scientific literacy approach in school science. International Journal of Science Education, 28(13), 1499-1521.

Newton, D. P., \& Newton, L. D. (2001). Subject content knowledge and teacher talk in the primary science classroom. European Journal of Teacher Education, 24(3), 369-379.

OECD (2006). Assessing scientific, reading and mathematical literacy: A framework for PISA 2006. Paris: OECD publications.

OECD (2007). PISA 2006: Science Competencies for Tomorrow's World, Vol. 1. Paris: OECD publications.

Osborne, J., \& Collins, S. (2001). Pupils' views of the role and value of the science curriculum: a focus-group study. International Journal of Science Education, 23(5), 441-467.

Osborne, J., Simon, S., \& Collins, S. (2003). Attitudes towards science: A review of the literature and its implications. International Journal of Science Education, 25(9), 1049-1079.

Oscarsson, M., \& Jidesjö, A. (2005). Organizing the relevance of science education (ROSE) survey in Sweden. Retrieved August 27, 2007, from Oslo University, Department of Teacher Education and School Developments Web site:

http://www.ils.uio.no/english/rose/network/countries/sweden/swe-report.pdf

Pajares (1992). Teachers' beliefs and educational research: cleaning up a messy construct. Review of Educational Research, 62(3), 307-332.

Roberts, D. A. (2007a). Linné scientific literacy symposium. Opening remarks by Douglas A. Roberts. In Linder, C., Östman, L. \& Wickman P-O. (eds) (2007). Promoting Scientific Literacy: Science Education Research in Transaction. Proceedings of the Linnaeus Tercentenary Symposium held at Uppsala University, Uppsala Sweden, May 28-29, 2007.

Roberts, D. A. (2007b). Scientific Literacy/Science Literacy. In Abell, S. \& Ledermann, N. (eds.). Handbook Of Research On Science Education (pp 729-780). New Jersey, Lawrence Erlbaum Associates Publishers. 
Sabatini, A., \& McLoughlin, S. (1999). Making science relevant: The experiences of prospective elementary school teachers in an innovative science content course. Journal of Science Teacher Education, 10(2), 69-91.

Schreiner, C., \& Sjøberg, S. (2004). Sowing the seeds of ROSE. Background, rationale, questionnaire development and data collection for ROSE (The Relevance of science Education) - a comparative study of students' views of science and science education. Oslo, Unipub AS.

Tan, M. C. (1988). Towards relevance in science education: Philippine context. International Journal of Science Education, 10(4), 431-440.

Trumbull, D. J., Scarano, G., \& Bonney, R. (2006). Relations among teachers practices and beliefs, conceptualizations of the nature of science, and their implementation of student independent inquiry projects. International Journal of Science Education, 28(14), 1717-1750.

Tsai, C-C. (2002). Nested epistemologies: Science teachers' beliefs of teaching, learning and science. International Journal of Science Education, 24(8), 771-783.

Tsai, C-C. (2007). Teachers' scientific epistemological views: The coherence with instruction and students' views. Science Education, 91(2), 222-243.

the National Swedish Agency for Education. (2006). Retrieved September 25, 2006, from the World Wide Web:

http://www3.skolverket.se/ki03/front.aspx?sprak=EN\&ar=0304\&skolform=11\&infotyp=2\&i $\mathrm{d}=11$.

van Zee, E. H., Iwasyk, M., Kurose, A., Simpson, D., \& Wild, J. (2001). Student and teacher questioning during conversations about science. Journal of Research in Science Teaching, 38(2), 159-190.

Waters-Adams, S. (2006). The relationship between understanding of the nature of science and practice: The influence of teachers' beliefs about education, teaching and learning. International Journal of Science Education, 28(8), 919-944.

Watts, M., Alsop, S., Gould, G., \& Walsh, A. (1997). Promoting teachers' constructive reflection: Pupils' questions as critical incidents. International Journal of Science Education, 19(9), 1025-1037. 